\title{
Relationship Between the Role of Parents and the Influence of Peers on the Consumption of Alcohol in Young Men in Hamlet VII Sei Rotan Village, Percut Sei Tuan District, Deli Serdang Regency
}

Supriati

Midwife Academy of Harapan Mama Deli Serdang, Jl. Batang Kuis KM 4,5 No. 10 Sei Rotan. Kec. Percut Sei Tuan, Kab. Deli Serdang, North Sumatra Province, 20371

\begin{tabular}{|c|c|}
\hline ARTICLE INFO & ABSTRACT \\
\hline $\begin{array}{r}\text { Article history: } \\
\text { Received Nov 15, } 2021 \\
\text { Revised Des 30, } 2021 \\
\text { Accepted Jan 23, } 2022\end{array}$ & $\begin{array}{l}\text { Abstract-Based on WHO data, western Europeans consume more } \\
\text { alcohol, people who consume the least alcohol are found in the } \\
\text { countries of Southern Asia. On the other hand, China, America and } \\
\text { Russia based on their population are the countries that consume the } \\
\text { most alcohol in the world. That sociologically the consumption of } \\
\text { alcoholic beverages in Indonesia is motivated by the customs and habits }\end{array}$ \\
\hline $\begin{array}{r}\text { Keywords: } \\
\text { The Role of Parents, } \\
\text { Peer Influence, } \\
\text { Consuming Alcohol }\end{array}$ & 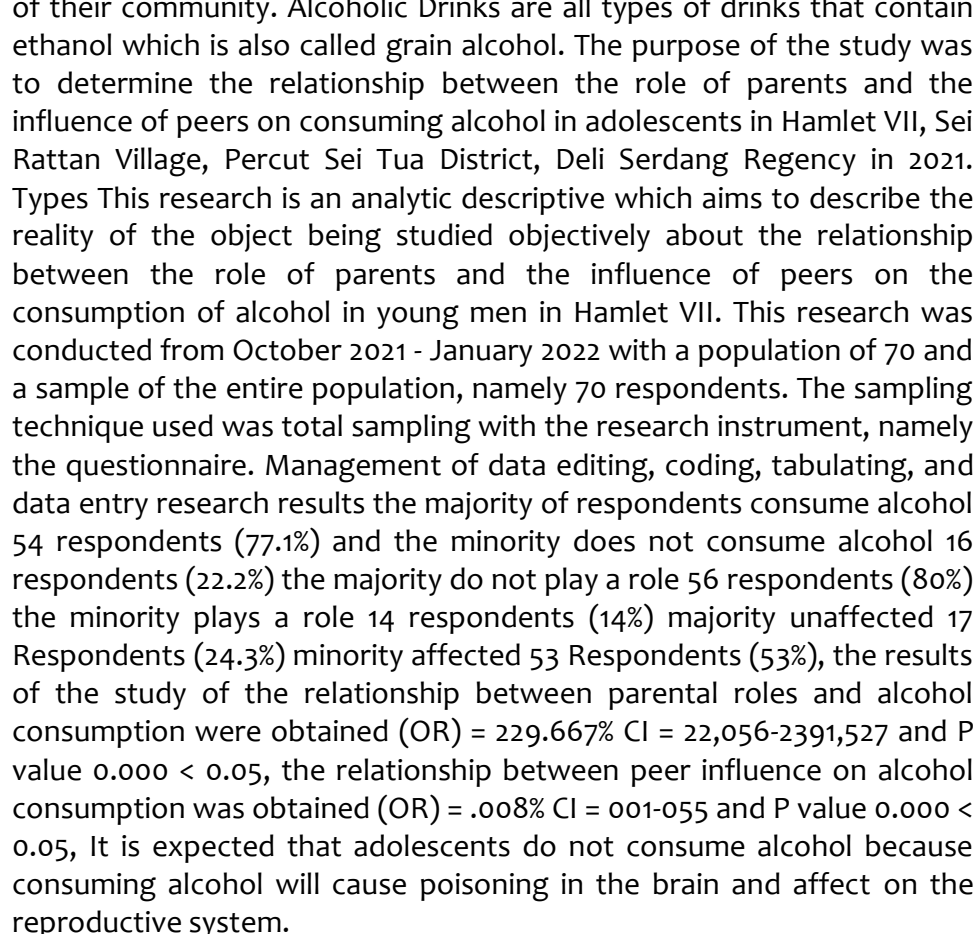 \\
\hline
\end{tabular}

This is an open access article under the CC BY-NC license.

\section{Corresponding Author:}

Supriati,

Kebidanan

Akademi Kebidanan Harapan Mama Deli Serdang,

Jl. Batang Kuis KM 4,5 No. 10 Sei Rotan. Kec. Percut Sei Tuan, Kab. Deli Serdang, Provinsi Sumatera Utara, 20371

Email: supriati 87.riri@gmail.com 


\section{Introduction}

Consuming alcohol is currently a fairly growing problem in the world and shows an increasing trend from year to year, due to the emergence of thugs in some areas due to young people who are addicted to alcohol, the effects of alcohol are more pronounced in young people than in adults because the bodies of teenagers still in the process of growing and developing. Teenagers also have not experienced the effects of drinking alcohol for teenagers is very dangerous. Alcohol is a very small molecule that is soluble in both water and fat so that it easily enters the bloodstream and also penetrates the blood brain barrier (Nurwijaya et al. 2009).

Based on WHO data, western Europeans consume more alcohol, while people who consume the least individual alcohol are found in southern Asian countries. On the other hand, China, America and Russia based on their total population are the countries that consume the most alcohol in the world (Nurwijaya ddk.2009. p.94).

WHO research results in 2007 in 12 countries on alcohol and accidents. It was found that out of 1.8 million deaths of the world's population each year due to alcohol. Half of these deaths are due to accidents when the victim consumes alcohol. Some people are from the lower classes. This is because, like in Indonesia, for example, news about alcohol victims from the upper class is rarely published (Nurwijaya ddk.2009. p.96).

In Indonesia, alcohol abuse is regulated by regional regulations (perda) in each region. That sociologically the consumption of alcoholic beverages in Indonesia is motivated by the customs and habits of their community. In some areas, the population's income depends on the sale of palm wine, water nira, brem or what is called "rice wine", ciu bekonang, Yogyakarta lapen, ballo or Toraja beer, Medan kamput, arak, stamp mice and others. (Nurwijaya ddk.2009, p.96). One of the Batak Toba culture, women who have just given birth to children need to drink palm wine to expedite their milk and sweat profusely to remove impurities from their bodies. Tuak is often used in traditional ceremonies there. In Kalimantan, palm wine is considered a symbol of sacrifice (Nurwijaya ddk.2009. p.55).

The habit of drinking alcohol on weekends until the teller never stopped. At that time, alcohol was very easy to obtain and could be bought at kiosks around the area where he lived. The first liquor you drink tastes bitter in your mouth but after feeling the sensation, you want to try again and again. (Nurwijaya ddk. 2009. p.99).

The effects of short-term alcohol consumption of approximately one large bottle make a person lack coordination such as not being able to walk properly and not being able to open the door in a short time this causes a hangover. Hangovers are usually caused by alcohol poisoning, other alcohol substances and as a result of alcohol addiction. Long-term effects will be felt after drinking it for several months or years (Nurwijaya ddk.2009. hlm.182).

Drinking alcohol for teenagers is very dangerous, they will do something and say something inappropriate when they are drunk (Nurwijaya ddk.2009. p.178). Consuming alcohol also leads to crime and criminal acts, such as muggings, theft, mugging, to murder. An addict will be desperate to commit a crime when he does not have money to buy alcoholic beverages. When he was hanging out with his fellow drunkards a fight broke out (Nurwijaya ddk.2009. hlm.173).

According to the Indonesian Demographic and Health Survey (IDHS 2017) revealed that the age of starting to consume alcoholic beverages, especially at the age of 15-19 years, the number of males tended to be more (70\%) compared to females (30\%) for reasons of curiosity, peer environment and excessive curiosity.

The World Health Organization (WHO) globally on alcohol and health reports that as many as 320,000 people aged 15-29 years die worldwide every year due to several causes related to alcohol and $51 \%$ of deaths in the world from diseases are related to alcohol consumption. In the world people die because of accidents due to alcohol with the dominance of male victims.

Based on Riskesdas 2018, the proportion of alcoholic beverage consumption habits in the last 1 month of the population aged 10 years in the province of North Sumatra based on the characteristics of the age $10-14$ years $0.59 \%, 15-19$ years $3.16 \%$ and $20-24$ years $6,79 \%$. Proportion of types of alcoholic 
beverages that are usually drunk by the population aged 10 years according to the characteristics of the age 10-14 years, beer $11.19 \%$, wine/arrack 20.82\%, Whiskey 0.00 , traditional cloudy drinks $57.35 \%$, beverages traditional clear $10.60 \%$, oplosan drink 0.00 , others $0.03 \%$. Age $15-19$ years old beer $19.92 \%$, wine/arrack $7.33 \%$, whiskey 0.00 , traditional cloudy drink $54.12 \%$, traditional clear drink $5.88 \%$, mixed drink $7.83 \%$, others 4, 92\%. Age 20-24 years beer $16.76 \%$, wine/arrack $6.97 \%$, whiskey $0.81 \%$, traditional cloudy drink $65.20 \%$, traditional clear drink $7.63 \%$, $0.92 \%$ oplosan drink, others $1,71 \%$. The average number of alcoholic beverages consumed by the population aged 10 years according to the characteristics of those aged $10-14$ years is $2.80 \%, 15-19$ years is $3.51 \%, 20-24$ years is $4.84 \%$. The proportion of consumption of harmful alcoholic beverages (harmful use of alcohol) of the population aged 10 years according to the characteristics of the age 10-14 years $0.09 \%, 15-19$ years $0.79 \%, 15-24$ years $1.55 \%$. Based on the proportion of consumption alcohol consumption in the population aged 10 years according to urban is $3.85 \%$ while Deli Serdang is a district with a total alcohol consumption of $7.43 \%$. The average number of alcoholic beverages consumed in urban areas is $4.54 \%$, in rural areas $3.68 \%$. The average consumption of alcoholic beverages is $0.91 \%$ in urban areas, $1.42 \%$ in rural areas.

Cross-sectors and health workers in Sei Rotan Village, Percut Sei Tuan District, Deli Serdang Regency always try to provide good health services by providing counseling to parents and adolescents so that they always avoid consuming alcohol. Especially parents who play an important role in paying attention to their sons in socializing, especially with their peers, because this curiosity and trial and error occurs a lot among teenagers in particular. The number of young men in hamlet VII is 70 people.

\section{Method}

sectional approach. The type of research that I do is descriptive analytical research. Descriptive research can be defined as a research conducted to describe or describe a phenomenon that occurs in society. In society, descriptive research is used to describe or photograph health problems and related to the health of a group of people or people in a particular community.

The population in this study were all young men of Hamlet VII, Sei Rotan Village, Percut Sei Tuan District, Deli Serdang Regency in October-January 2022 with a total of 70 people. The samples used in this study were all the young men of Hamlet VII, Sei Rotan Village, Percut Sei Tuan District, Deli Serdang Regency, with a total of 70 people. Sample size The sample size is the number of members to be sampled. The sampling technique in this study uses a non-probability technique, namely a saturated sample or often called total sampling. Saturated sample is a sampling technique by taking all members of the population as respondents or samples. So the sample in this study was all young men from Hamlet VII, Sei Rotan Village, Percut Sei Tuan District, Deli Serdang Regency, namely as many as 70 young men (Notoatmodjo, 2012).

Data analysis with Univariate Analysis Performed by calculating the frequency in the form of a percentage of the variables studied. And Bivariate Analysis X $2=\Sigma($ ) Information: $X 2=$ Chi-square $=$ Total Data $\mathrm{O}=$ Observation Value $\mathrm{E}=$ Expected value The conclusions from the statistical test results are as follows: a. If $\times 2$ count $\times 2$ table, Ho is rejected or $\mathrm{Ha}$ is accepted, meaning that there is a relationship between the independent variable and the dependent variable. b. If $x 2$ count $<x 2$ table, Ho is accepted or $\mathrm{Ha}$ is rejected, it means that there is no relationship between the independent variable and the dependent variable. 


\section{Analysis And Results}

Table 1

Univariate Analysis

Distribution of the frequency of consuming alcohol, the role of parents, the influence of peers

\begin{tabular}{|c|c|c|}
\hline Category & $\mathrm{N}$ & $\%$ \\
\hline \multicolumn{3}{|c|}{ Frequency of consuming alcohol } \\
\hline Consumes & 54 & 77,1 \\
\hline Not Consuming & 16 & 22,9 \\
\hline Total & 70 & 100 \\
\hline \multicolumn{3}{|c|}{ Parental Role Frequency } \\
\hline Play & 14 & 20,0 \\
\hline No Role & 46 & 80,0 \\
\hline Total & 70 & 100 \\
\hline \multicolumn{3}{|c|}{ Peer Influence Frequency } \\
\hline Affected & 53 & 75,7 \\
\hline unaffected & 17 & 24,3 \\
\hline Total & 70 & 100 \\
\hline
\end{tabular}

According to the Big Indonesian Dictionary (KBBI) the meaning of the word consumption is the use of manufactured goods (clothing, food, etc.). Another meaning of consumption is goods that directly meet the needs of our lives. According to Linelejan et al.'s 2017 research on "Adolescent Behavior About Consumption of Alcoholic Beverages in Touliang Village, Kakas Barat District, Minahasa Regency." The results show that the probability value between knowledge and action of alcohol consumption $p=0.205$ and between attitudes and actions of consuming alcoholic beverages $p=0.000$. The results of this study indicate that there is no relationship between knowledge and actions of consuming alcoholic beverages and there is a relationship between attitudes and actions of alcohol consumption. The results showed that the majority of teenagers who consumed alcohol were 39 teenagers $(75.0 \%)$ and the minority who did not consume alcohol were 13 teenagers (25.0\%). This is because there is no supervision from parents, teenagers want to try new things, especially with the act of consuming alcoholic beverages which is influenced by environmental factors in Touliang village.

According to Amalia's 2015 research on "The Role of Parents on Alcohol Consumption in Adolescent Boys in Sidoarjo Village, Sugio District, Lamongan Regency in 2015" The results of the research found a significant relationship between the role of parents and alcohol consumption in adolescents with $\mathrm{P}$ values $=0.000$ and $\mathrm{rs}=0.749$. The results of the study showed that from 14 adolescents the role of parents, either entirely or $100 \%$ of children consumed low levels of alcohol, while 16 adolescents had less parental roles, some or $50 \%$ of their children consumed moderate levels of alcohol. This is due to the example figure of parents, the inability of parents to control their emotions makes children temperamental, difficult to manage, tend to commit crimes and have the opportunity to consume alcohol to relieve the burden faced by their parents. their children in controlling children and caring for their children and the work of parents related to the level of delinquency committed by their children, such a situation because it is possible for farmers or private employees to just be busy making a living to meet family needs, so there is less attention to naming values. and social norms to children. As a result of all that many teenagers who consume alcohol.

Peer groups have a big role and influence on a teenager's life. Social interaction and peer affiliation have a big role in encouraging the formation of various social skills. For teenagers, the home is the basic foundation while the 'world' is school. In the adolescent development phase, Children not only admire their parents but also admire figures outside the home environment such as peers, teachers, friends' parents, athletes and others. According to Yafi's 2018 research on the Relationship between Peer Pressure and Alcohol Drinking Behavior in Adolescents in Malang City "The results of his research show that there is a relationship between peer pressure and drinking behavior $(r=0.149 p=0.020)$. This is 
because teenagers follow their peers because their thinking is still unstable and they want to be accepted in a very high group and their peers consume alcohol. The sense of prestige that teenagers have will make them affected by negative and positive things.

Table 2

Bivariate Analysis

The Relationship of the Role of Parents with Consuming Alcohol More about this source text

\begin{tabular}{|c|c|c|c|c|c|c|c|c|}
\hline \multirow{3}{*}{$\begin{array}{l}\text { the Role } \\
\text { of Parents }\end{array}$} & \multicolumn{4}{|c|}{ Consuming Alcohol } & \multirow{2}{*}{\multicolumn{2}{|c|}{ Total }} & \multirow{3}{*}{$\begin{array}{c}\text { OR } \\
(95 \% \mathrm{Cl})\end{array}$} & \multirow{3}{*}{$\begin{array}{c}\mathrm{P} \\
\text { value }\end{array}$} \\
\hline & \multicolumn{2}{|c|}{ Consuming } & \multicolumn{2}{|c|}{ Not Consuming } & & & & \\
\hline & $\mathbf{N}$ & $\%$ & $\mathbf{N}$ & $\%$ & $\mathbf{N}$ & $\%$ & & \\
\hline No role & 53 & $94.6 \%$ & 3 & $5.4 \%$ & 56 & $100.0 \%$ & 229.667 & \\
\hline role & 1 & $7.1 \%$ & 13 & $92.9 \%$ & 14 & $100.0 \%$ & $(22.056-2391.527)$ & 0.000 \\
\hline Total & 54 & $77.1 \%$ & 16 & $22.9 \%$ & 70 & $100.0 \%$ & & \\
\hline
\end{tabular}

The results of the study revealed that from 56 respondents the role of parents who did not play a role in consuming alcohol was 53 respondents, $94.6 \%$ consumed and the role of parents who did not consume alcohol was 3 respondents $5.4 \%$ did not consume. Of the 14 respondents the role of parents who play a role in consuming alcohol as much as 1 respondent $7.1 \%$ and the role of parents who play a role in consuming alcohol as much as 13 respondents $92.9 \%$ do not consume.

The results of the analysis of the relationship between the role of parents on consuming alcohol that the statistical test results obtained the value of Odd Ratio $(O R)=229.667 \% \mathrm{Cl}=22.056-2391.527$ and $\mathrm{P}$ value $0.000<0.05$, which means there is a significant relationship between the role of parents to consume alcohol in young men. The role of parents who are inattentive and the lack of time given to their sons and parents' indifference to their teenage children causes these teenagers to consume alcohol, many teenagers imitate the actions of parents who also drink alcohol.

Table 3

The Relationship of Peer Influence with Consuming Alcohol

\begin{tabular}{|c|c|c|c|c|c|c|c|c|}
\hline \multirow{3}{*}{$\begin{array}{l}\text { The Relationship } \\
\text { of Peer Influence }\end{array}$} & \multicolumn{4}{|c|}{ Consuming Alcohol } & \multirow{2}{*}{\multicolumn{2}{|c|}{ Total }} & \multirow{3}{*}{$\begin{array}{c}\text { OR } \\
(95 \% \mathrm{CI})\end{array}$} & \multirow{3}{*}{$\begin{array}{c}\mathrm{P} \\
\text { value }\end{array}$} \\
\hline & \multicolumn{3}{|c|}{ Consuming } & $\begin{array}{l}\text { Not } \\
\text { Consuming }\end{array}$ & & & & \\
\hline & $\mathbf{N}$ & $\%$ & $\mathbf{N}$ & $\%$ & $\mathbf{N}$ & $\%$ & & \\
\hline Not affected & 3 & $17.6 \%$ & 14 & $82.4 \%$ & 17 & $100.0 \%$ & .008 & \\
\hline Affected & 51 & $96.2 \%$ & 2 & $3.8 \%$ & 53 & $100.0 \%$ & $(.001-055)$ & 0.000 \\
\hline Total & 54 & $77.1 \%$ & 16 & $22.9 \%$ & $70 \%$ & $100,0 \%$ & & \\
\hline
\end{tabular}

The results showed that 17 respondents were influenced by their peers who were not affected by alcohol consumption, as many as 3 respondents, $17.6 \%$ consumed and influenced by peers who were not affected by alcohol consumption, as many as 14 respondents, $82.4 \%$ did not consume. Of the 53 respondents the influence of peers who are affected to consume alcohol as many as 51 respondents $96.2 \%$ consume and the influence of peers who influence the consumption of alcohol as much as 2 respondents $3.8 \%$ do not consume.

The results of the analysis of the relationship between the influence of peers on consuming alcohol that the statistical test results obtained the value of Odd Ratio $(\mathrm{OR})=.008 \% \mathrm{Cl}=001-055$ and $\mathrm{P}$ value $0.000<0.05$, which means that there is a significant relationship between the role of parents on alcohol consumption in young men.

According to Anugraheni's 2018 research on "The Relationship between Peer Associations and Alcoholic Drinking Behavior in Adolescent Boys in Dusun Padan Keji Mutilan, Magelang, Central Java 2018". Category of Medium Peer Association (88.9\%) while Alcoholic Behavior is Moderate (91.1\%). From

Supriati, Relationship between the role of parents and the influence of peers on the consumption of alcohol in young men in Hamlet VII Sei Rotan Village, Percut Sei Tuan District, Deli Serdang Regency 
the results of the Kendall Tau test, a p value of $0.001(p<5 \%)$ with a correlation coefficient of 0.572 indicates a moderate close relationship. There is a relationship between peers and alcohol behavior in adolescent boys in the Padan Keji Mutilan Hamlet, Magelang, Central Java 2018. This is This is due to peer association with drinking behavior in teenage boys, the higher the negative peer association, the more drinking behavior. The influence or association of many peers causes teenagers to consume alcohol, because it is called slang and is considered great from their peers.

\section{Conclusion}

Based on the results of the research and discussion that has been presented, the following conclusions are obtained: Based on consuming alcohol as many as 54 people (77.1\%) and not consuming alcohol as many as 16 people (22.2\%). No role as many as 56 people (80.0\%) and as many as 14 people (14\%). Not affected $A$ total of 17 people (24.3\%) and affected as many as 53 people (53\%). The results of the analysis of the relationship between the role of parents on consuming alcohol that the statistical test results obtained the value of Odd Ratio $(O R)=229.667 \% \mathrm{Cl}=22.056-2391.527$ and $\mathrm{P}$ value $0.000<0.05$, which means there is a significant relationship between the role of parents to consume alcohol in young men. The results of the analysis of the relationship between the influence of peers on consuming alcohol that the statistical test results obtained the value of Odd Ratio $(O R)=.008 \% \mathrm{Cl}=001-055$ and $\mathrm{P}$ value 0.000 $<0.05$, which means that there is a significant relationship between the role of parents on alcohol consumption in young men.

\section{References}

Anugraheni Setyo Dyah (2018). Hubungan Pengaruh Pergaulan Teman Sebaya

Dengan Perilaku Minum-Minuman Keras Pada Remaja Laki-Laki Di Dusun Padan Keji Muntilan Magelang Jawa Tengah

http://digilib.unisayogya.ac.id/4336/1/NASPUB_DYAH\%20SETYO\%20ANUGRAHENI_201410201026.pdf diakses pada 15 Februari 2021

Dhamayanti Meita,dkk (2010). Bunga Rampai Kesehatan Remaja.Jakarta:Badan Penerbit Dokter Anak Indonesia

Departemen Pendidikan dan Kebudayaan (1999).Kamus Besar Bahasa Indonesia.Balai Pustaka,Jakarta

Hidayat Alimul Azizi A (2010). Metode Penelitihan Kebidanan dan Teknik Analisi Data, Jakarta. Salemba Medika

Harry Hoer Aly (2007). Ilmu Pendidikan Islam. Lobos Wacana Ilmu:Jakarta

Nurwijaya Hartati (2009). Bahaya Alkohol Dan Cara Mencega Kecanduannya, Jakarta. Gramedia

Notoatmodjo Soekidjo 2010). Metodologi Penelitihan Kesehatan, Jakarta. Rineka Cipta Di Akses 28 Februari 2021

Prihatin Agung(2014). Hubungan Antara Pengaruh Teman Sebaya Dan PolaAsuh Orang Tua Dengan Perilaku Mengkonsumsi Minuman Keras Pada Remaja Di Desa Cangkol Sragen http://eprints.ums.ac.id/30906/16/NASKAH_PUBLIKASI.pdf diakses 15 Februari 2021

Proverawati (2017).Menarche (menstruasi pertama penuh makna),Yogyakarta. Nuhamedika

Prayugo Hadi Bayutirta (2014). Hubungan Pola Asuh Orang Tua Dengan Perilaku Mengkonsumsi Minuman Beralkohol Pada Kecamatan Jenggawah Jember http://download.garuda.ristekdikti.go.id/article.HUBUNGAN PERAN ORANGTUADENGANPERILAKUKONSUMSIMINUMANALKOHOLPADAREMAJALAKI-LAKI.pdf diakses 22 Februari 2021

Riskesdas (2018). Konsumsi Minuman Beralkohol, Badan Litbang Kesehatan 
http://www.pusat3.litbang.kemkes.go.id/dwn.php?file=LAPORAN\%20RISKESDAS\%20SUMUT\%202018.pdfdi akses 22 Februari 2021

Shochib (2018).Pola Asuh Orang Tua Dalam Membantu Anak Mengembangkan Disiplin Diri. Jakarta: Rineka Cipta,

Sugiyono (2019).Metode penelitian kuantitatif, kualitatif, dan R\&D. Alfabeta, Bandung

Snyder Gail (2007). Remaja \& Alkohol. Intan Sejati: Bandung

Soejono Soekanto (1988). Sosiologi Suatu Pengantar. Cv Rajawali : Jakarta 